\title{
Dead wood volume to dead wood carbon: the issue of conversion factors
}

\author{
K. Weggler $\cdot$ M. Dobbertin • E. Jüngling • \\ E. Kaufmann $\cdot$ E. Thürig
}

Received: 3 August 2011/Revised: 24 November 2011/ Accepted: 3 January 2012/Published online: 25 February 2012

(c) Springer-Verlag 2012

\begin{abstract}
Requirements for emission reporting under the Kyoto protocol demand an estimate of the dead wood carbon pool in forests. The volume of dead wood consists of coarse woody debris, smaller woody debris and dead roots. The measurement of dead wood volume was included in the most recent National Forest Inventory in Switzerland. To convert dead wood volume into carbon two conversion factors are required: (a) carbon (C) concentration and (b) wood density. So far internationally accepted default values for C concentration $(50 \%)$ and for wood density (density of alive trees) were used as default values to estimate dead wood carbon, since local measurements were lacking. However, in a field study at 34 sites in Switzerland, the C concentration and density of CWD from Picea abies and Fagus sylvatica of four decay classes were measured recently. The results showed that $\mathrm{C}$ concentration in CWD differed significantly between species but did not change due to decay class. The density of CWD decreased significantly with an increase in decay class and it also differed between species. The decrease in CWD density was more pronounced for $F$. sylvatica than for $P$. abies. We assessed correlations between climate attributes and CWD density using regression analysis. The modeled densities and measured $\mathrm{C}$ concentrations were then expanded with
\end{abstract}

Communicated by C. Ammer.

K. Weggler $(\square) \cdot$ E. Kaufmann · E. Thürig

Resource Analysis und Predictions, Swiss Federal Institute for

Forest, Snow and Landscape Research (WSL),

8903 Birmensdorf, Switzerland

e-mail: karinweggler@yahoo.de

M. Dobbertin · E. Jüngling

Forest Dynamics, Swiss Federal Institute for Forest, Snow and

Landscape Research (WSL), 8903 Birmensdorf, Switzerland the help of CWD volume data from the NFI3. Spruce CWD and thus spruce CWD carbon is much more abundant in Swiss forests than beech CWD carbon. The majority of spruce CWD is located in the Alps and Pre-Alps. The CWD volume from $P$. abies was 10 times higher than that from $F$. sylvatica. Thus, changes in conversion factors for $P$. abies CWD affected the overall estimate of dead wood carbon in Swiss forests much more than changes in conversion factors for $F$. sylvatica CWD. Current improvements in CWD conversion factors decreased the estimated amount of spruce CWD carbon by $23.1 \%$ and that of beech by $47.6 \%$. The estimated amount of CWD carbon in Swiss forests is decreased by $31 \%$. Since improved estimation methods are currently not applied to smaller woody debris and dead root material, the estimated amount of dead wood carbon is only reduced by $15 \%$. Improving conversion factors for all dead wood fractions would presumably decrease the amount of dead wood carbon by additional $16 \%$.

Keywords Carbon - Coarse woody debris - Wood density - Picea abies - Fagus sylvatica - Dead wood carbon . Conversion factors - Green house gas accounting

\section{Introduction}

Many countries, such as Switzerland, have joined the United Nations Framework Convention on Climate Change (UNFCCC) and ratified the additional Kyoto Protocol that regulates emission reduction commitments. Requirements for emission reporting have been defined in the Convention and the Kyoto Protocol. Thus, Switzerland is required to report annual emissions from many sectors including Land use, Land use change and Forestry (LULUCF). In the 
LULUCF section countries have to report removals or sinks of greenhouse gas (GHG) under Article 3.3 (aforestation and deforestation) and can elect to do so under Article 3.4 (forest management) of the Kyoto protocol. Switzerland has decided to include forest management under Article 3.4 in their accounting of anthropogenic GHG emission and removal and needs to provide the required reporting under this section. For this report, changes of carbon in plants, dead wood and soil must be estimated for managed forest, which have been established prior to 1990 . The quantity of carbon in dead organic matter is a significant reservoir in many of the world's forests (IPCC 2003). So far measurement of dead wood is less established in National Forest Inventories (NFI) than measurement of alive trees (Tomppo et al. 2010; Woodall et al. 2009). Until now knowledge about dead wood volume in Swiss Forests was limited because criteria for coarse woody debris and the minimum diameter for coarse woody debris was altered over time to serve a shift in demand for information (Böhl and Brändli 2007).

The dead wood pool consists of different fractions such as woody debris from fallen stems, standing dead trees, dead coarse roots and other dead material not included in the litter or soil carbon pools (IPCC 2003). For practical reasons, the Swiss NFI distinguishes between (a) bigger size woody debris that includes fallen dead trees and snags (d $>12 \mathrm{~cm})$, (b) smaller woody debris $(7<\mathrm{d}>12 \mathrm{~cm})$ and (c) dead coarse roots. A comprehensive measurement of those dead wood volumes was included in the most recent NFI for Switzerland (Böhl and Brändli 2007; Cioldi et al. 2010). Those three dead wood fractions contain dead wood volume approximately in the ratio $2: 1: 1$ (Cioldi et al. 2010).

To convert volume measurements into carbon, two conversion factors are necessary: (1) C concentration and (2) density. If local measurements for those factors are not available, the IPCC good practice guidance (IPCC 2003) supplies default values. The default value for $\mathrm{C}$ concentration of wood is $50 \%$, for instance. The default value for dead wood density is the density of alive wood from Picea abies $\left(0.40 \mathrm{~g} \mathrm{~cm}^{-3}\right)$ and Fagus sylvatica $\left(0.58 \mathrm{~g} \mathrm{~cm}^{-3}\right)$. Very similar default values from local studies of alive wood (Assmann 1961) were used so far to calculate dead wood carbon in the Swiss GHG inventory (FOEN 2009). However, Lamlon and Savidge (2003) found that C content varies substantially among species and that a $50 \%$ generic value is an oversimplification of limited application in relation to global warming and the concept of carbon credits. Furthermore, density of dead wood is likely to be dependent on its state of decay (Harmon et al. 1987, 1986). Harmon et al. (1986) stated that if dead wood volume is multiplied with the default wood density of fresh wood then the carbon content of this part of the ecosystem is usually overestimated. For more accurate estimates of dead wood carbon, the decay rate-specific dead wood density for all major tree species needs to be established under local conditions. Decay class-specific $\mathrm{C}$ concentration and density values were measured recently for spruce and beech coarse woody debris at 34 sites in Switzerland (Jüngling, pers. com.). These measurements need to be extrapolated to the whole forest area of Switzerland. One method to apply the measured coarse woody debris-density values to the NFI database is by using decay class-specific density values, irrespective of local differences. Alternatively, measured density values can be used to establish a model that predicts site-specific coarse woody debris-density values on the basis of local climate attributes, provided correlations between climate attributes and wood density can be found.

The key factors that influence the decay process and thus wood density are (1) the environment and (2) substrate quality (Laiho and Prescott 2004). A number of models have been established to predict litter decay on the basis of climate attributes (Kurz-Besson et al. 2006; Meentemeyer 1978), and a few models have been established to predict CWD decay (Mackensen et al. 2003; Yin 1999). Major climate attributes used in models vary between studies. Mean annual temperature was often found to determine woody debris decomposition (Gough et al. 2007; Liski et al. 2003; Mackensen et al. 2003; Meentemeyer 1978). For leaf litter decay, it was found that temperature and a factor for drought can explain a majority of the variability in decay (Liski et al. 2003; Meentemeyer 1978). Rainfall and the resulting water content of wood were also shown to increase their decay rates (Gough et al. 2007). Explanatory variables in models can vary due to the state of decay. Heim and Frey (2004) found that the early stages of leaf litter decay were determined by litter quality parameters whereas later stages were determined by climate attributes. All those studies found some correlations between climate attributes and debris decay. At least in the first three phases of wood decay, also wood density decreases significantly over time (Müller-Using and Bartsch 2009). Hence, it appears possible that CWD density, as a surrogate for CWD decay, could be modeled on the basis of climate attributes for the notable time span that dead wood remains within one decay class.

The volume of dead wood can depend on a range of factors, such as tree species, climate and management, to name the most important ones (Fig. 1). The volume of coarse woody debris in mixed forests of Switzerland, as provided by the NFI3, was found to be on average $21.5 \mathrm{~m}^{3} \mathrm{ha}^{-1}$ and is considered high in European comparison (Brändli et al. 2010). Spruce (P. abies) and beech (F. sylvatica) are the two major species in Swiss forest, together equating to about $60 \%$ of the forest biomass 


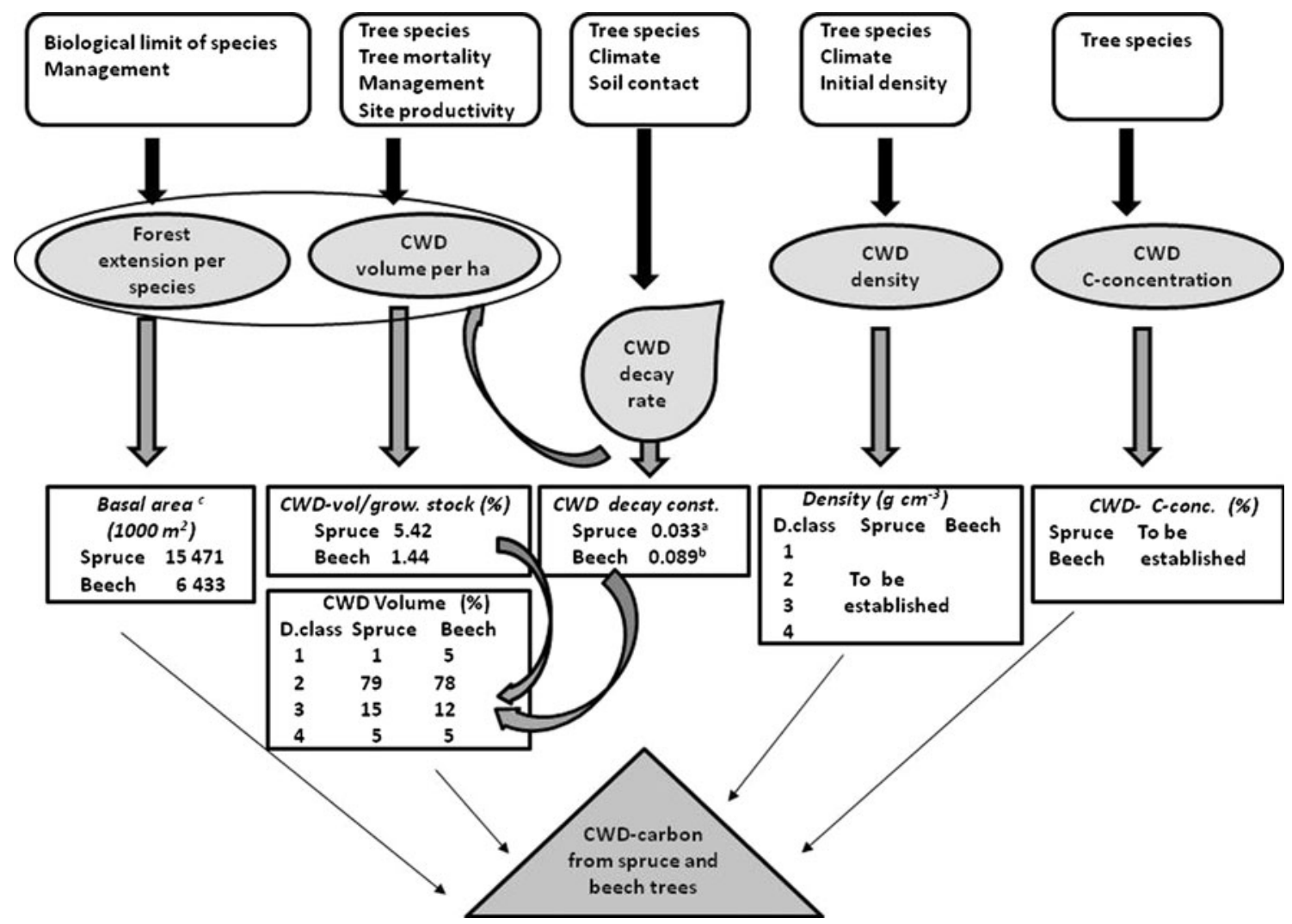

Fig. 1 Factors that can influence the amount of CWD carbon (Round cornered fields), 'values' necessary to estimate it (ellipsoid fields). Current information necessary to quantify 'values' are provided if available (Rectangle fields). ${ }^{\mathrm{a}}$ from Rock et al. (2008); ${ }^{\mathrm{b}}$ from Müller-

(Cioldi et al. 2010). Differences in dead wood volume between species have been reported previously, with $25 \mathrm{~m}^{3}$ $\mathrm{ha}^{-1}$ for managed spruce and $5 \mathrm{~m}^{3} \mathrm{ha}^{-1}$ for managed beech forests (Bretz-Guby and Dobbertin 1996). A generally lower dead wood volume for spruce of $2-10 \mathrm{~m}^{3} \mathrm{ha}^{-1}$ has been reported for Scandinavia (Siitonen 2001). If the dead wood volume differs between species, then knowledge about changes in conversion factors for tree species alone is still a limited indicator to forecast changes to the overall dead wood carbon estimate for Switzerland. Knowledge about species-specific conversion factors and volumes is necessary to judge major carbon pools and forecast potential changes to them.

To improve the accuracy of the estimated amount of dead wood carbon for Switzerland, the current study has four aims. The first aim is to extrapolate the survey based, decay class-specific $\mathrm{C}$ concentration and density values for spruce and beech to the Swiss NFI3-database.

The second aim is to further improve the estimates of coarse woody debris density by taking local climate into account. The objective is to predict site-specific coarse woody debris density with the help of climate-based models. The third aim is to assess the impact of changes in
Using and Bartsch (2009); ${ }^{\mathbf{c}}$ Forest extension provided as basal area due to the high amount of mixed forests in Switzerland. Abbreviation for decay class: $d$. class

conversion factors on the estimated amount of coarse woody debris carbon. The fourth aim is to apply the improved conversion factors based on spruce and beech to the coarse woody debris in mixed forests of Switzerland. The study will focus on coarse woody debris carbon, but implications for smaller woody debris and dead coarse roots carbon will be discussed.

\section{Materials and methods}

Dead wood pools

In the NFI3, three pools of dead wood were measured or estimated at 6,608 sites: bigger size woody debris, smaller size woody debris and dead roots (estimated).

In this publication, the term CWD is used for snags, lying dead trees and stumps with a diameter (above bark) of $\geq 12 \mathrm{~cm}$ at breast height ( $\mathrm{dbh}$ ). To determine CWD, all lying and standing dead wood, including stumps, was measured in a circular area of 200 or $500 \mathrm{~m}^{2}$ for bigger size stems $(\mathrm{d}>34 \mathrm{~cm})$. The method is described in detail by Keller (2005). The dbh was measured $1.3 \mathrm{~m}$ above the original 
surface. Soil material on top of the dislocated root stock was used to estimate the original surface. Diameter was measured above bark, if still attached and otherwise around the remaining trunk. Broken stems were estimated as separate units. The top part of dead stems that fell below a diameter of $12 \mathrm{~cm}$ was accounted for in the LIS pool (see below). For stumps, the volume was assessed from height and diameter at cut off point. The volume of CWD was estimated according to functions published in Kaufmann (2001).

The volume of generally smaller sized woody debris such as lying stems, pieces of stems, branches and other woody debris with a diameter of $7<\mathrm{d}<12 \mathrm{~cm}$, excluding snags, is determined by the line intersect method (Keller 2005) and is termed LIS in this publication. All smaller size woody debris was estimated for a circular area of $200 \mathrm{~m}^{2}$ by measuring the small woody debris that intersects with three lines, $10 \mathrm{~m}$ length each, that star like capture the round sample area (lines in $120^{\circ}$ angles).

The mass of dead roots (in the following termed D Roots), in $\mathrm{kg}$, is estimated as a function of diameter of the measured dead trees in the CWD fraction, according to Wirth et al. (2004) and Wutzler et al. (2008).

The CWD, as measured in the NFI3, is classified into five decay classes according to methods outlined in Table 1 (Keller 2005). The origin of CWD in terms of tree species was recorded in the field if it could be determined. For most CWD samples, about $87 \%$ of CWD volume, tree species could be determined. Even for decay class 4 , tree species could be determined for about $50 \%$ of the CWD volume. The volume of CWD and the distribution of CWD volume between the five decay classes for spruce and beech are given in Table 2 .

Switzerland has a high percentage of mixed forests. To be able to compare the volume of CWD per hectare for spruce and beech, the area that each species potentially occupies needed to be estimated. We used basal area (BA) ratios to calculate the area covered by one species. For instance, BAspruce to BA-coniferous trees was assumed to be similar to area-spruce to area-coniferous trees. The same calculation was conducted for beech. Using the estimated area covered by spruce or beech trees, we calculated the volume of CWD per area for spruce and beech. The basal area of spruce, beech, coniferous and deciduous trees and calculated amount of CWD per hectare is given in Table 3.

\section{Density and C concentration of CWD}

The $\mathrm{C}$ concentration and density of CWD and of living trees was determined at 34 trial sites of the Swiss national forest health inventory (Sanasilva, subset of the NFI sites)

Table 1 Coarse woody debris classification system, terms and method of determination in the field (Keller 2005)

a not analyzed in this study

\begin{tabular}{lll}
\hline Decay class & Term & Method of determination \\
\hline 0 & Alive tree & - \\
1 & Fresh wood & Stem still contains sap \\
2 & Dead wood & No sap, firm, a knife hardly can penetrate along the fibers \\
3 & Rotten wood & Less firm, knife penetrates along the fibers easily, but not diagonally \\
4 & Moldy wood & Soft, the knife penetrates in each direction easily \\
$5^{\text {a }}$ & Mulm wood & Very soft and powdery, hardly hanging together \\
\hline
\end{tabular}

Table 2 Spruce and beech CWD volume per decay class and for the five NFI regions of Switzerland

\begin{tabular}{|c|c|c|c|c|c|c|c|c|c|c|c|c|}
\hline \multirow[b]{2}{*}{ Decay class } & \multicolumn{12}{|c|}{ CWD volume $\left(1,000 \mathrm{~m}^{3}\right)$} \\
\hline & Jura & SEM & Plateau & SEM & Pre-Alps & SEM & Alps & SEM & South. Alps & SEM & Switzerland & SEM \\
\hline \multicolumn{13}{|l|}{ Spruce } \\
\hline 1 & 11 & 7 & 47 & 21 & 24 & 10 & 30 & 10 & 1 & 1 & 113 & 26 \\
\hline 2 & 463 & 68 & 821 & 162 & 2,997 & 337 & 2,931 & 250 & 431 & 86 & 7,643 & 463 \\
\hline 3 & 24 & 9 & 91 & 24 & 303 & 52 & 838 & 100 & 178 & 44 & 1,434 & 124 \\
\hline 4 & 9 & 7 & 32 & 16 & 62 & 18 & 268 & 50 & 80 & 29 & 452 & 63 \\
\hline Sum & 507 & 68 & 917 & 171 & 3,386 & 349 & 4,067 & 302 & 690 & 108 & 9,641 & 509 \\
\hline \multicolumn{13}{|l|}{ Beech } \\
\hline 1 & 1 & 1 & 18 & 13 & 3 & 2 & 13 & 12 & 14 & 13 & 50 & 22 \\
\hline 2 & 186 & 54 & 196 & 52 & 244 & 61 & 136 & 37 & 65 & 18 & 827 & 105 \\
\hline 3 & 22 & 11 & 61 & 33 & 7 & 4 & 27 & 11 & 10 & 5 & 127 & 37 \\
\hline 4 & 5 & 3 & 10 & 7 & 7 & 5 & 15 & 11 & 18 & 12 & 55 & 19 \\
\hline Sum & 215 & 58 & 284 & 63 & 261 & 61 & 191 & 50 & 108 & 27 & 1,058 & 120 \\
\hline
\end{tabular}

Data from the NFI3 (Speich et al., 2010). Standard error (SEM) is shown 
Table 3 Forest area, basal area, growing stock, CWD volume and calculated amount of CWD per hectare, listed for coniferous, deciduous, spruce and beech trees. Data from the NFI3 (Cioldi et al. 2010) unless labelled with an ${ }^{\mathrm{a}}$

\begin{tabular}{|c|c|c|c|c|c|}
\hline Source & $\begin{array}{l}\text { Forest } \\
\text { area (ha) }\end{array}$ & $\begin{array}{l}\text { Basal areab } \\
\left(1,000 \mathrm{~m}^{2}\right)\end{array}$ & $\begin{array}{l}\text { Grow. stock }{ }^{b} \\
\left(1,000 \mathrm{~m}^{3}\right)\end{array}$ & $\begin{array}{l}\text { CWD volume } \\
\left(1,000 \mathrm{~m}^{3}\right)\end{array}$ & $\begin{array}{l}\text { CWD volume } \\
\left(\mathrm{m}^{3} \mathrm{ha}^{-1}\right)\end{array}$ \\
\hline Spruce & $480,185^{\mathrm{a}}$ & $15,471(3,02)$ & $178,799(3,253)$ & $9,691(509)$ & $20.2(1.0)$ \\
\hline Coniferous trees & & $24,159(359)$ & $277,924(3,955)$ & $14,962(503)$ & $12.8(0.5)$ \\
\hline Coniferous tree dominated forest & 749,841 & & & & $19.9(1.1)$ \\
\hline Beech & $223,297^{\mathrm{a}}$ & $6,433(167)$ & $73,346(1,844)$ & $1,058(119)$ & $4.7(0.5)$ \\
\hline Deciduous trees & & $12,168(246)$ & $127,450(2,454)$ & $3,709(160)$ & $3.2(0.2)$ \\
\hline Deciduous tree dominated forest & 422,365 & & & & $8.8(0.4)$ \\
\hline Total forest & $1,172,200$ & $36,334(405)$ & $405,374(4,393)$ & $18,733(553)$ & $16.0(0.5)$ \\
\hline Ratio: spruce/beech & 2.2 & 2.4 & 2.4 & 9.2 & 4.3 \\
\hline Ratio: coniferous/deciduous & & 2.0 & 2.2 & 4.0 & 4.0 \\
\hline
\end{tabular}

a Calculated using ratio: spruce basal area/coniferous basal area, and beech basal area/deciduous basal area

b Standard error (SEM) is given in brackets

and the long-term forest ecosystem research network (LWF) (Innes 1995; WSL 2010). The CWD of spruce was sampled at 21 sites and the CWD of beech at 19 sites. These sites represent the five NFI regions of Switzerland and also the major environmental and climatic conditions found in spruce and beech forests in Switzerland (Table 4, Fig. 2).

The CWD was classified according to the CWD classification system adopted in the NFI3 (Keller 2005). The CWD and living wood samples were taken between June and August 2009. Wood cores from living stems (length $=15 \mathrm{~mm}, \mathrm{~d}=5 \mathrm{~mm}$ ) were taken at the base of the tree using a dendro corer. The CWD samples were taken along dead stems, where the degree of decay appeared uniform. Preferably trunks with known mortality dates were sampled. However, for trunks showing higher decay status, the mortality had occurred prior plot installation. Samples from those trunks were taken when species of origin could be determined. The samples were about a fist full of material $\left(500-1,000 \mathrm{~cm}^{3}\right)$ and were taken using an axe. Samples with higher degree of decay were cut out using a knife. Five replicate samples were taken for decay class $0-4$ at each site. No samples were taken for decay class 5 (Mulmholz) since sampling is difficult, and handling (vacuum packing) would have caused erroneous readings for density. Furthermore, only $0.4 \%$ of total CWD volume in NFI 3 was in decay class 5 .

After taking the fresh weight of samples, the dry weight was determined after drying at $105^{\circ} \mathrm{C}$ for $48 \mathrm{~h}$. The volume of CWD was measured by the method of water displacement. For this purpose, each sample was vacuum packed and volume was determined. In prior tests, we compared volume estimated using the water displacement and vacuum packing method with volume determined using geometrical volume calculations. We found the estimates to be within $\pm 5 \%$ difference with no systematic error. Density was calculated as the ratio of fresh volume to dry weight. One of the 5 replicate samples per decay class and site was subsampled prior to drying. The subsample was dried at $65^{\circ} \mathrm{C}$ and analyzed for $\mathrm{C}$ and $\mathrm{N}$ concentration using an element analyzer (Carlo Erba Instruments NC 2500). The remaining water content of samples dried at $65^{\circ} \mathrm{C}$ was determined by further drying some of the sample material at $105^{\circ} \mathrm{C}$. The $\mathrm{C}$ concentration was calculated in two ways (a) as $\mathrm{C}_{65}$, which implies that the $\mathrm{C}$ concentration was calculated relative to the mass determined at $65^{\circ}$ and (b) as $\mathrm{C}_{105}$, the $\mathrm{C}$ concentration relative to the mass determined at $105^{\circ}$. Unless stated, the $\mathrm{C}$ concentration is provided as $\mathrm{C}_{105}$ in the results.

Climate models to predict CWD density

Models to explain variability in CWD density were established separately for spruce and beech. The wood quality of angiosperm and gymnosperm is very different in terms of wood density, $\mathrm{C}$ concentration and $\mathrm{C} / \mathrm{N}$ ratio (Weedon et al. 2009) and thus species were analyzed separately.

The list of climate and environmental attributes, which have been tested in the regression analysis, are given in Table 5. Annual and monthly rainfall and average annual and average monthly temperature data are based on climate data from the Federal Office of Meteorology and Climatology of Switzerland, with surface data calculated according to the method of Thornton et al. (1997). The surface data of potential evapotranspiration were calculated according to the empirical equation by Turc (1963). The attribute drought in this publication is the difference between the sum of monthly rainfall minus the sum of daily potential evapotranspiration for that month (daily values multiplied by 30 or 31 ). 
Table 4 Location, type of inventory site, NFI region, average annual temperature, annual rainfall and altitude of the sampling sites for spruce and beech CWD

\begin{tabular}{|c|c|c|c|c|c|c|c|}
\hline Inventory $^{\mathrm{a}}$ & $\begin{array}{l}\text { Location } \\
\text { (North/East) }^{\mathrm{c}}\end{array}$ & NFI region & $\begin{array}{l}\text { Annual } \\
\text { temperature }\left({ }^{\circ} \mathrm{C}\right)\end{array}$ & $\begin{array}{l}\text { Annual } \\
\text { rainfall }(\mathrm{mm})\end{array}$ & $\begin{array}{l}\text { Altitude } \\
\text { (m) }\end{array}$ & $\begin{array}{l}\text { Mean annual } \\
\text { evapotranspiration. } \\
\left(\mathrm{mm} \mathrm{day}^{-1}\right)\end{array}$ & $\begin{array}{l}\text { Summer } \\
\text { drought }(\mathrm{mm})^{\mathrm{b}}\end{array}$ \\
\hline \multicolumn{8}{|l|}{ Spruce } \\
\hline 1 & $498000 / 145000$ & Jura & 5.2 & 1,762 & 1,230 & 1.17 & 329 \\
\hline 1 & $546000 / 209000$ & Jura & 5.5 & 1,557 & 1,110 & 1.38 & 259 \\
\hline 1 & $562000 / 225000$ & Jura & 6.1 & 1,469 & 1,022 & 1.43 & 224 \\
\hline 2 & $598335 / 230470$ & Jura & 5.4 & 1,642 & 1,150 & 1.31 & 344 \\
\hline 1 & $514000 / 161000$ & Plateau & 3.2 & 1,932 & 1,575 & 1.17 & 438 \\
\hline 1 & $562000 / 193000$ & Plateau & 9.1 & 976 & 475 & 1.84 & -55 \\
\hline 1 & $706000 / 257000$ & Plateau & 7.4 & 1,377 & 712 & 1.50 & 260 \\
\hline 2 & $540171 / 159464$ & Plateau & 7.5 & 1,209 & 800 & 1.67 & 76 \\
\hline 2 & $633909 / 236004$ & Plateau & 8.7 & 1,122 & 480 & 1.69 & 62 \\
\hline 1 & $690000 / 209000$ & Pre-Alps & 7.7 & 1,751 & 650 & 1.34 & 533 \\
\hline 2 & $696800 / 211631$ & Pre-Alps & 5.4 & 2,149 & 1,150 & 1.17 & 759 \\
\hline 2 & $624757 / 172177$ & Pre-Alps & 3.9 & 1,630 & 1,500 & 1.29 & 461 \\
\hline 1 & $610000 / 113000$ & Alps & 3.8 & 844 & 1,635 & 0.71 & 144 \\
\hline 1 & $690000 / 177000$ & Alps & 4.3 & 1,420 & 1,355 & 0.88 & 371 \\
\hline 1 & $642000 / 161000$ & Alps & 3.0 & 1,532 & 1,650 & 0.94 & 462 \\
\hline 1 & $658000 / 145000$ & Alps & 2.3 & 1,517 & 1,820 & 1.00 & 262 \\
\hline 1 & $754000 / 161000$ & Alps & 1.1 & 1,375 & 1,977 & 0.92 & 462 \\
\hline 1 & $802000 / 177000$ & Alps & 3.1 & 850 & 1,580 & 0.77 & 224 \\
\hline 2 & $784500 / 187700$ & Alps & 2.7 & 1,134 & 1,600 & 0.91 & 314 \\
\hline 2 & $762589 / 174074$ & Alps & 3.9 & 1,098 & 1,450 & 1.15 & 263 \\
\hline 2 & $705538 / 144866$ & S. Alps & 5.0 & 1,703 & 1,350 & 0.88 & 573 \\
\hline \multicolumn{8}{|l|}{ Beech } \\
\hline 1 & $578000 / 225000$ & Jura & 5.6 & 1,552 & 1,112 & 1.27 & 276 \\
\hline 1 & $498000 / 145000$ & Jura & 5.2 & 1,762 & 1,230 & 1.17 & 329 \\
\hline 1 & $562000 / 209000$ & Jura & 6.7 & 1,228 & 930 & 1.29 & 160 \\
\hline 1 & $578000 / 257000$ & Jura & 8.8 & 1,035 & 450 & 1.78 & -5 \\
\hline 1 & $594000 / 241000$ & Jura & 7.0 & 1,370 & 832 & 1.37 & 238 \\
\hline 2 & $598335 / 230470$ & Jura & 5.4 & 1,642 & 1,150 & 1.31 & 344 \\
\hline 2 & $682373 / 282029$ & Jura & 8.1 & 1,027 & 580 & 1.37 & 82 \\
\hline 1 & $562000 / 177000$ & Plateau & 7.8 & 1,171 & 740 & 1.70 & 80 \\
\hline 1 & $562000 / 193000$ & Plateau & 9.1 & 976 & 475 & 1.84 & -55 \\
\hline 1 & $578000 / 209000$ & Plateau & 8.6 & 1,096 & 555 & 1.78 & -1 \\
\hline 1 & $626000 / 225000$ & Plateau & 8.3 & 1,188 & 555 & 1.68 & 102 \\
\hline 2 & $540171 / 159464$ & Plateau & 7.5 & 1,209 & 800 & 1.67 & 76 \\
\hline 2 & $659495 / 250156$ & Plateau & 8.7 & 1,124 & 480 & 1.73 & 57 \\
\hline 2 & $633909 / 236004$ & Plateau & 8.7 & 1,122 & 480 & 1.69 & 62 \\
\hline 1 & $658000 / 209000$ & Pre-Alps & 7.4 & 1,457 & 790 & 1.29 & 385 \\
\hline 1 & $690000 / 209000$ & Pre-Alps & 7.7 & 1,751 & 650 & 1.34 & 533 \\
\hline 2 & $723464 / 225068$ & Pre-Alps & 7.3 & 1,891 & 780 & 1.26 & 624 \\
\hline 1 & $578000 / 113000$ & Alps & 6.1 & 1,183 & 1,192 & 1.23 & 139 \\
\hline 2 & $721303 / 109369$ & S. Alps & 6.8 & 1,993 & 1200 & 1.13 & 757 \\
\hline
\end{tabular}

a (1) Sanasilva (sites coincide with NFI sites) (2) LWF

b Summer Drought $=$ precipitation (May-September)—evapotranspiration (May-September)

c Swiss country coordinate system LV03 
Fig. 2 Location of sites, where spruce and beech CWD was sampled for analysis. The five NFI regions are indicated with different background coloring

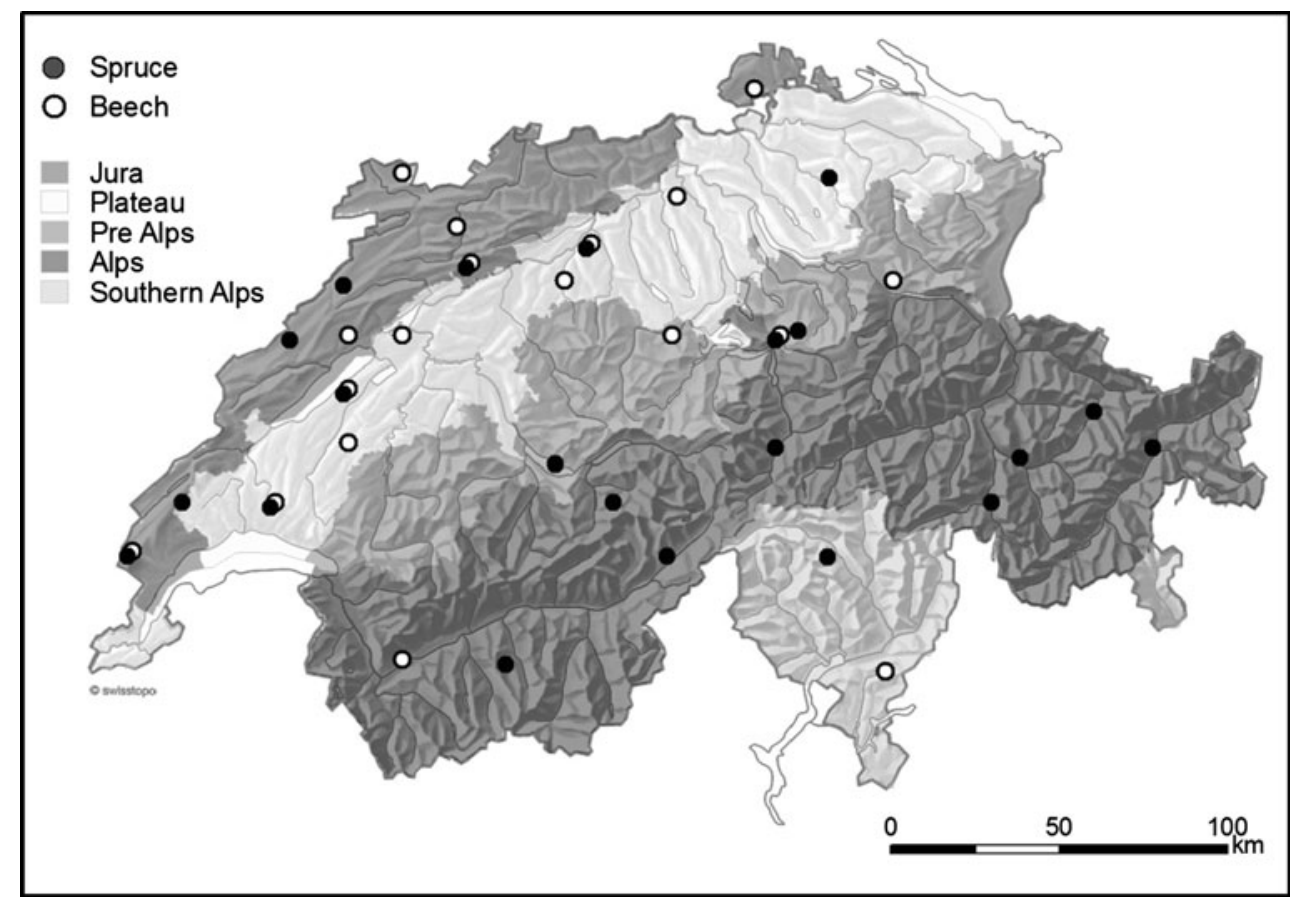

Table 5 Climate and environmental attributes tested in the regression analysis

\begin{tabular}{|c|c|c|c|c|}
\hline Attribute & Term & Data & Month $^{\mathrm{a}}$ & Method \\
\hline Mean annual temperature & Temp & $1961-1990$ & & Thornton et al. (1997) \\
\hline Mean monthly temperature & TempMonth & $1961-1990$ & $1,6,7$ & Thornton et al. (1997) \\
\hline Mean annual rainfall & Rain & $1961-1990$ & & Thornton et al. (1997) \\
\hline Mean monthly rainfall & Rain Month & $1961-1990$ & $1,6,7$ & Thornton et al. (1997) \\
\hline Mean daily potential evapotranspiration, averaged per month & EvMonth & 1966-2006 & $6,7,8,9$ & Turc (1963) \\
\hline Mean monthly drought factor ${ }^{b}$ & DroMonth & $1961-2006$ & 6,7 & Rain Month-30*EvMonth ${ }^{\mathrm{b}}$ \\
\hline Elevation & Height & & & \\
\hline NFI region & Region & & & Brändli et al. (2010) \\
\hline
\end{tabular}

a Month given as: January (1), February (2), March (3), April (4), May (5), June (6), July (7), August (8), September (9), October (10), November (11), December (12)

b EvMonth was multiplied with 30 or 31 , depending on the number of days per month

Statistical analysis and regression models

The influence of climate and environmental attributes on CWD density was tested using linear regression analysis (reg, stepwise forward selection, SAS 9.1) or nonlinearregression analysis (nlin) when linear regression did not fit. Statistical analysis was performed separately for spruce and beech data, due to observed interactions when using the whole data set. Models were established separately for each decay class, due to observed interactions between decay class, density and the influence of temperature. Standard errors (SEM) of the combined estimate of CWD carbon as given in Table 9, 10 and 11 was calculated as follows:
Combined estimate : $d=a \times b \times c$

$$
\begin{aligned}
\operatorname{SEM}_{d} & =\operatorname{SQRT}\left[\left(\operatorname{SEM}_{a} / \bar{a}\right)^{2}+\left(\operatorname{SEM}_{b} / \bar{b}\right)^{2}\right. \\
+ & \left.\left(\operatorname{SEM}_{c} / \bar{c}\right)^{2}\right] \times \bar{d}
\end{aligned}
$$

$d$, combined estimate of CWD carbon; $a, \mathrm{C}$ conc.; $b, \mathrm{CWD}$ density; $c$, CWD volume. The SEM $_{\text {attribute }}$ is the respective standard error of each attribute. If standard error of a given attribute was unknown, then double the SEM of the measured attribute of our study was taken. When the SEM for CWD carbon of coniferous and deciduous species was calculated (Table 11), then the SEM for density and C concentration for spruce and beech again was doubled. 
Methods of carbon estimation

The amount of CWD carbon depends on (a) CWD C concentration (b) CWD density and (c) CWD volume. In the sensitivity analysis, we estimated the amount of CWD carbon for two species according to Methods $1-4$, as outlined in Table 6. Method 1 uses default values, as set out by the IPCC (1997): a general C concentration of 50\% and country specific, average wood density of alive trees (values for Switzerland are as follows: spruce: $0.39 \mathrm{~g} \mathrm{~cm}^{-3}$, beech: $0.56 \mathrm{~g} \mathrm{~cm}^{-3}$ according to Assmann (1961)). Method 2 uses species-specific CWD C concentration and default values for CWD density. Method 3 uses species-specific CWD C concentration and average values of species and decay classspecific CWD density. Method 4 uses species-specific CWD $\mathrm{C}$ concentration and species- and site-specific CWD density values as predicted by climate-based regression models. For all methods, the CWD volume as measured in the NFI3 was used (Cioldi et al. 2010).

Coarse woody debris volume scenarios

Changes in growing stock can increase or decrease CWD volume. With a range of scenarios in terms of growing stock and resulting CWD volume, we assessed the impact of changes in CWD volume on the estimated amount of CWD carbon. All scenarios were assessed according to the following assumption: In the NFI3, spruce CWD volume was $5.4 \%$ and beech CWD volume was $1.44 \%$ of their respective growing stock (Cioldi et al. 2010). Those percentages were assumed to remain stable, and potential regional variations were not taken into account.

The result of changes in CWD volume on the estimated amount of CWD carbon was assessed in scenario 1-4 for spruce and scenario 11-44 for beech. A change in growing stock in the order of $10-20 \%$ is realistic, since the growing stock of beech has increased by $6 \%$ and that of deciduous trees by $10 \%$ between LFI2 and 3 (Cioldi et al. 2010). Growing stock of spruce has decreased by $4 \%$ and that of coniferous trees by $1 \%$ during the same time. Although changes in growing stock usually take place gradually, for our estimates, we assumed a forest in steady state with a higher level of growing stock.

In scenario 5 and 55, the impact of a change in Forestry management on the estimated amount of CWD carbon was assessed. Arbitrarily it was assumed that the amount of 'wood used for energy' from 1 year, as published by the Swiss Forestry Statistics (Swiss Forestry Statistics 2010) for 2009 , is left in the forest. About $482,000 \mathrm{~m}^{3}$ coniferous and $1,066,000 \mathrm{~m}^{3}$ of deciduous wood were used for energy production in 2009 . This is about $14 \%$ of the total amount of traded coniferous wood and $70 \%$ of deciduous wood in 2009. The volume of growing stock necessary to produce merchantable wood is about $32 \%$ higher than the volume of merchantable wood (Kaufmann and Brassel 1999), because some components and some trees are not usable for trade. The volume of this respective growing stock was converted into carbon by using $\mathrm{C}$ concentration and density of fresh wood as conversion factors. This is due to the assumption that wood used for energy wood presumably consists of recently fallen or felled trees.

\section{CWD in mixed forests of Switzerland}

The volume of CWD for coniferous and deciduous trees, as measured in the NFI3, is shown in Table 3. The total amount of CWD carbon for the mixed species forests of Switzerland was calculated according to Methods $1-4$. The CWD $\mathrm{C}$ concentration and density values of spruce were used for all coniferous CWD, and those of beech were used for all deciduous tree CWD. Based on those numbers, we calculated the CWD carbon that exists in conifer dominated forests and in deciduous tree dominated forests.

Dead wood carbon from the LIS and DRoots pool

To simulate the effect of improved conversion factors on the LIS and DRoot pools, we estimated the amount of dead

Table 6 Input values used for CWD C concentration, CWD density and CWD volume to estimate the amount of CWD carbon from spruce and beech trees in forest areas of Switzerland, according to Methods 1-4

\begin{tabular}{lllll}
\hline Attribute & Description & Method & \\
\cline { 3 - 5 } & & 1 & 2 & 3 \\
\hline CWD C conc. & IPCC default value of 50\% C conc. in CWD & X & X & X \\
CWD density & Species-specific C concentration of CWD & X & X \\
& Species-specific density of fresh wood & & X \\
& Species-specific CWD density for decay class 1-4 & & X \\
CWD volume & Models based on climate variables to predict site- and & X & X \\
\hline
\end{tabular}


wood carbon for those pools as well according to method 4 . To be able to calculate this, we assumed that the volume distribution between decay class 1-4 for LIS and D Roots was the same as for CWD and that density in decay class 1-4 decreased in the same way as for CWD.

\section{Results}

Carbon concentration and density of CWD

Spruce and beech CWD differed significantly in $\mathrm{C}$ concentration, $\mathrm{N}$ concentration and $\mathrm{C} / \mathrm{N}$ ratio. The $\mathrm{C}_{105}$ concentration of spruce CWD was $49.3 \%$ and beech CWD $47.6 \%$ (Table 7). However, $\mathrm{C}_{105}$ concentrations were not significantly different in the four decay classes for both species. The $\mathrm{C}_{65}$ concentrations were lower than the $\mathrm{C}_{105}$ concentrations. The absolute difference between $\mathrm{C}_{65}$ and $\mathrm{C}_{105}$ determined values is $1 \%$ for spruce and $0.8 \%$ for beech CWD.

The density of spruce and beech CWD decreased significantly with an increase in decay class (Fig. 3). From decay class $1-4$, spruce CWD density decreased by $36 \%$ from 0.39 to $0.25 \mathrm{~g} \mathrm{~cm}^{-3}$ and beech CWD density decreased by $56 \%$ from 0.52 to $0.23 \mathrm{~g} \mathrm{~cm}^{-3}$. In fresh wood and decay class 1, CWD density was significantly different between species. In decay classes 2, 3 and 4, the density was similar for the two species (Fig. 3).

\section{Climate models to predict CWD density}

Significant correlations between local climate attributes and CWD density allowed to establish some predictive models. Models varied with species and decay class. The models with the best fit are listed in Table 8. Climate models explained up to $22 \%$ of the variability in spruce CWD density and up to $7 \%$ in beech CWD density. The density of spruce CWD is mainly influenced by annual rainfall. In decay class 1 and 4, temperature and potential evapotranspiration additionally have a significant influence. For beech, models to predict CWD density could only be established for decay classes 2 and 4 . The factor drought is correlated with beech CWD density in decay class 2 and 4, but overall correlations were weak. For decay class 1 and 3, the average measured density values could not be improved.

\section{Methods of carbon estimation}

In the sensitivity analysis, we estimated carbon for spruce and beech CWD according to Methods 1-4. Results are listed in Table 9. Improving the accuracy for CWD C concentration reduced the estimated amount of CWD carbon for spruce by $1.4 \%$ and for beech by $4.7 \%$ (Method 2 compared to 1). Improving the accuracy of CWD density values reduced the estimated amount of CWD carbon for spruce by additional $17.8 \%$ and for beech by additional $41.6 \%$ (Method 3 compared to 1). Including climate models to predict site-specific CWD density reduced the estimated amount of CWD carbon again for spruce by $3.9 \%$ and for beech by $1.3 \%$ (Method 4 compared to 3 ).

Although relative changes in CWD carbon due to improved estimation methods appear more pronounced for beech CWD, absolute changes are more pronounced for spruce CWD. For instance, differences in the total amount of spruce CWD carbon estimated according to Method 1

Table 7 Average $\mathrm{C}_{65}, \mathrm{C}_{105}, \mathrm{~N}_{65}$ concentration, $\mathrm{C}_{65} / \mathrm{N}_{65}$ ratio and water content of spruce- and beech CWD from decay class $1-4$

\begin{tabular}{|c|c|c|c|c|c|c|}
\hline Decay class & $\mathrm{C}_{65}(\%)$ & $\mathrm{C}_{105}(\%)$ & $\mathrm{N}_{65}(\%)$ & $\mathrm{C}_{65} / \mathrm{N}_{65}$ ratio $(\%)$ & Water- cont. ${ }_{\left(65^{\circ} \mathrm{C}\right)}(\%)$ & Water- cont. $\left(65-105^{\circ} \mathrm{C}\right)(\%)$ \\
\hline \multicolumn{7}{|l|}{ Spruce } \\
\hline 1 & $47.9 \mathrm{a}$ & $48.7 \mathrm{a}$ & $0.189 \mathrm{~cd}$ & $257 \mathrm{~b}$ & $38 \mathrm{c}$ & $1.72 \mathrm{a}$ \\
\hline 2 & $48.1 \mathrm{a}$ & $49.1 \mathrm{a}$ & $0.286 \mathrm{c}$ & $204 \mathrm{bc}$ & $55 \mathrm{bc}$ & $1.97 \mathrm{a}$ \\
\hline 3 & $48.7 \mathrm{a}$ & $49.7 \mathrm{a}$ & $0.417 \mathrm{~b}$ & $172 \mathrm{c}$ & $98 \mathrm{~b}$ & $1.99 \mathrm{a}$ \\
\hline 4 & $48.9 \mathrm{a}$ & $49.6 \mathrm{a}$ & $0.603 \mathrm{a}$ & $83 \mathrm{~d}$ & $274 \mathrm{a}$ & $2.09 \mathrm{ab}$ \\
\hline Average & 48.3 & 49.3 & & & & 1.94 \\
\hline \multicolumn{7}{|l|}{ Beech } \\
\hline 1 & $47.0 \mathrm{a}$ & $47.7 \mathrm{a}$ & $0.309 \mathrm{~d}$ & $166 \mathrm{~b}$ & $43 \mathrm{c}$ & $1.47 \mathrm{a}$ \\
\hline 2 & $46.8 \mathrm{a}$ & $47.6 \mathrm{a}$ & $0.433 \mathrm{c}$ & $121 \mathrm{c}$ & $92 \mathrm{c}$ & $1.57 \mathrm{a}$ \\
\hline 3 & $46.5 \mathrm{a}$ & $47.3 \mathrm{a}$ & $0.640 \mathrm{~b}$ & $82 \mathrm{~d}$ & $242 \mathrm{~b}$ & $1.64 \mathrm{a}$ \\
\hline 4 & $46.9 \mathrm{a}$ & $47.9 \mathrm{a}$ & $0.860 \mathrm{a}$ & $61 \mathrm{~d}$ & $317 \mathrm{a}$ & $2.14 a b$ \\
\hline average & 46.8 & 47.6 & & & & 1.71 \\
\hline
\end{tabular}




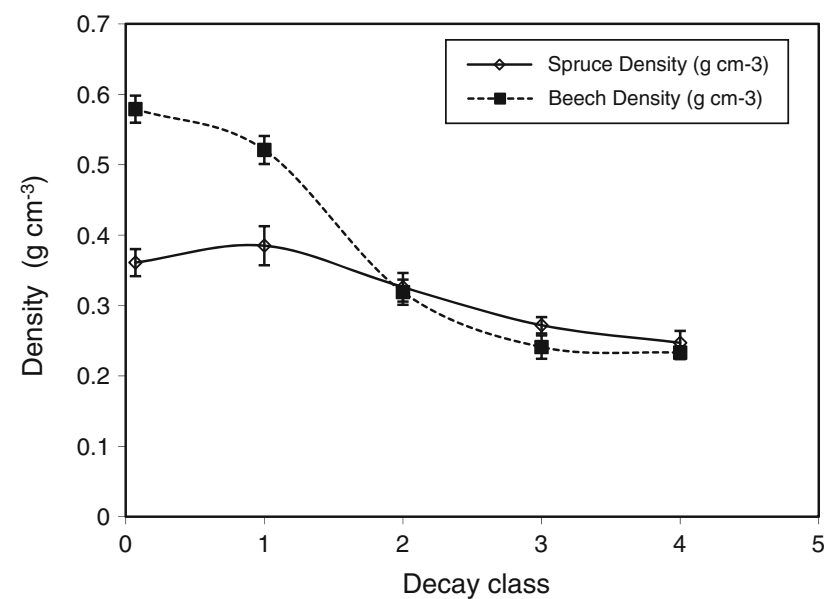

Fig. 3 Average density of CWD (decay class 1 to 4) from spruce (Picea abies) and beech (Fagus sylvatica). The average density from wood of alive trees is provided as decay class 0 . The standard errors are indicated (bars) compared to Method 4 are 434,000 t C, but only 141,000 t $\mathrm{C}$ for beech CWD (Table 9). Higher absolute changes in spruce compared to beech CWD carbon are due to a significantly higher volume of spruce CWD compared to beech CWD. The CWD volume of spruce is about 9 times higher compared to beech, although the area covered by spruce and the basal area of spruce is only about 2.4 times higher compared to beech trees (Table 3 ). The calculated CWD volume per hectare is $20.2 \mathrm{~m}^{3} \mathrm{ha}^{-1}$ for spruce and $4.7 \mathrm{~m}^{3} \mathrm{ha}^{-1}$ for beech (Table 3 ). The estimated amount of CWD carbon per calculated spruce or beech area is 3 and $0.69 \mathrm{t} \mathrm{C} \mathrm{ha}^{-1}$, respectively (Table 3 and 9).

The distribution of CWD carbon per species and NFI regions, estimated according to Method 3, is shown in Fig. 4. Most CWD volume and CWD carbon is stored in decay class 2 for both species (Fig. 4, Table 2). Significantly more carbon is stored in spruce than in beech CWD. Spruce CWD in the Pre-Alps and Alps stores by far the

Table 8 Best-fitting models established using linear or nonlinear regression analysis (SAS) for each decay class (D. class)

\begin{tabular}{llr}
\hline D. class & Model & \\
\hline Spruce & & $R^{2}$ \\
1 & Density $=\exp (-0.526-2.590$ (EvJune) +2.293 (EvJuly)-0.00185 (Rain) +0.0625 (Temp)) & 0.22 \\
2 & Density $=0.51211-0.01998$ (EvJune) -0.00095158 (Rain) & 0.19 \\
3 & Density $=\exp (-0.9409-0.00256$ (Rain) $)$ & 0.10 \\
4 & Density $=0.28018+0.31860$ (EvJune)-0.31326 (EvJuly) \\
Beech & & \\
1 & Density $=0.52$ & 0.12 \\
2 & Density $=\exp (-1.0975-0.00129$ (DroJune) $)$ & 0.06 \\
3 & Density $=0.24$ & 0.07 \\
4 & Density $=\exp (-1.4590-0.00161$ (DroJuly) $)$ &
\end{tabular}

The coefficient of determination $\left(R^{2}\right)$ is given for each model. Only climatic attributes with an $F$-Probability $<0.15^{\mathrm{a}}$ are listed

A more stringent significance limit of $F$-Probability $<0.05$ would have reduced the predictive value of models

${ }^{a}$ Significance level of $F$-Probability $<0.15$ is the default limit for significance in this routine, provided by SAS 9.1

Table 9 Estimated amount of CWD carbon, calculated according to Methods 1-4, from spruce or beech

\begin{tabular}{|c|c|c|c|c|c|c|c|}
\hline Method & $\begin{array}{l}\text { Growing stock } \\
\left(1,000 \mathrm{~m}^{3}\right)\end{array}$ & $\begin{array}{l}\text { CWD/Grow. } \\
\text { stock }(\%)\end{array}$ & $\begin{array}{l}\text { CWD volume } \\
(1,000 \mathrm{~m})^{3}\end{array}$ & $\begin{array}{l}\text { CWD density (decay class } 1 \text {, } \\
2,3,4)\left(\mathrm{g} \mathrm{cm}^{-3}\right)\end{array}$ & $\begin{array}{l}\text { CWD } \mathrm{C}_{105} \\
\text { conc. }(\%)\end{array}$ & $\begin{array}{l}\text { Total CWD carbon } \\
(1,000 \text { t C) }\end{array}$ & $\begin{array}{l}\mathrm{SEM}^{\mathrm{b}} \\
(1,000 \mathrm{t} \mathrm{C})\end{array}$ \\
\hline \multicolumn{8}{|l|}{ Spruce } \\
\hline 1 & 178,799 & 5.42 & 9,691 & $0.39^{\mathrm{a}}$ & 0.500 & 1,880 & 197 \\
\hline 2 & & & & $0.39^{\mathrm{a}}$ & 0.493 & 1,854 & 192 \\
\hline 3 & & & & $0.39 ; 0.33 ; 0.28 ; 0.25$ & 0.493 & 1,519 & 117 \\
\hline 4 & & & & Models & 0.493 & 1,446 & 111 \\
\hline \multicolumn{8}{|l|}{ Beech } \\
\hline 1 & 73,346 & 1.44 & 1,058 & $0.56^{\mathrm{a}}$ & 0.500 & 296 & 40 \\
\hline 2 & & & & $0.56^{\mathrm{a}}$ & 0.476 & 282 & 38 \\
\hline 3 & & & & $0.52 ; 0.32 ; 0.24 ; 0.23$ & 0.476 & 159 & 21 \\
\hline 4 & & & & Models & 0.476 & 155 & 20 \\
\hline
\end{tabular}

a Density of wood from living trees, according to Assman (1961)

b Combined standard error (SEM) is shown 

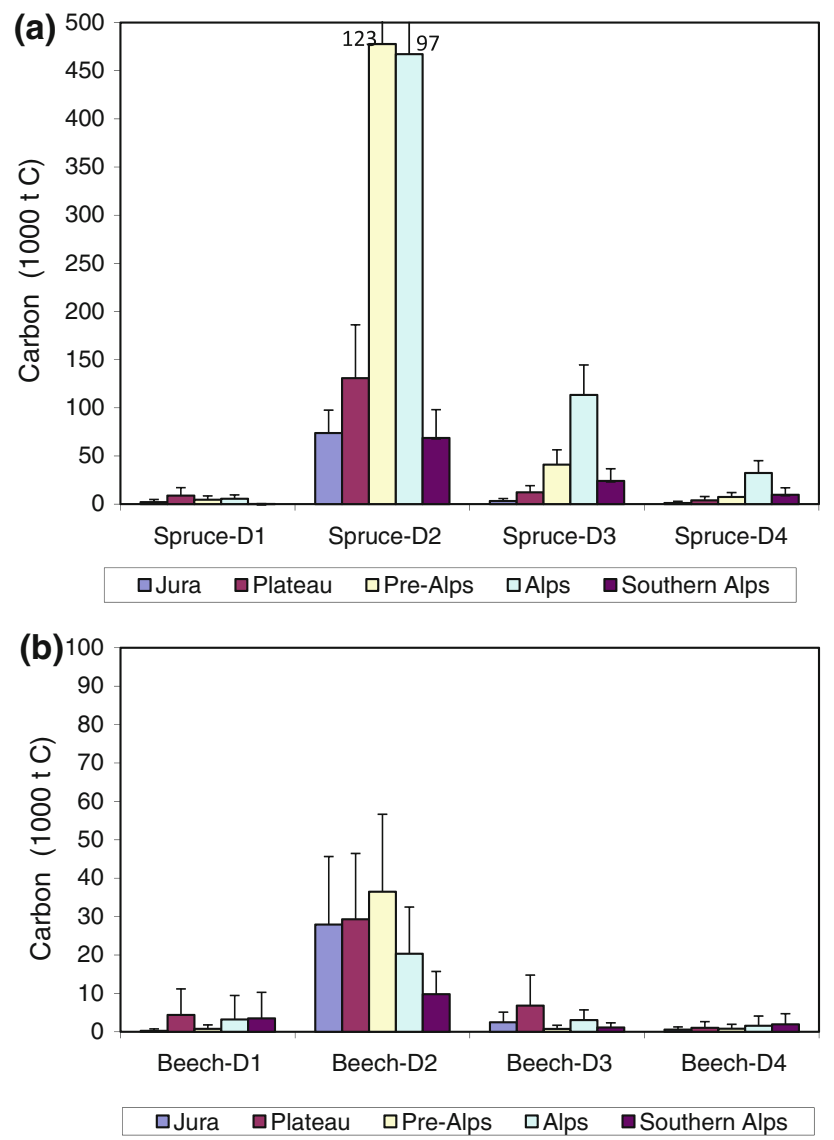

Fig. 4 Amount of CWD carbon in decay classes 1-4 (D1-D4) from a spruce (Picea abies) and b beech (Fagus sylvatica) in the five NFI regions of Switzerland, estimated according to Method 3. (Standard error shown)

major amount of CWD volume and CWD carbon. Spruce CWD also stores the major amount of carbon in regions such as the Plateau or the Jura, where beech trees are more abundant than spruce (Fig. 4).

\section{Scenarios for CWD volume}

The influence of CWD volume on the estimated amount of CWD carbon was assessed by estimating CWD carbon under five different scenarios. Results are listed in Table 10. Expansion of spruce growing stock by $20 \%$ would increase the estimated amount of spruce CWD carbon by $11 \%$ or, in absolute terms, by 188,000 t C (Scenario 1 compared to 0, Table 10). The same expansion in beech growing stock would increase the estimated amount of beech CWD carbon by $6 \%$ or 9,000 t $\mathrm{C}$ (Scenario 11 compared to 00 ).

Scenario 5 and 55 assessed the impact of leaving the wood used for energy of 1 year in the forest to decay (Table 10). This measure would increase the amount of spruce CWD carbon by $7.3 \%$ and of beech CWD carbon by
236\%. The total amount of spruce and beech CWD carbon would be increased by $29.5 \%$ compared to the current amount of CWD carbon due to this management intervention (Scenario 5 plus 55 compared to 0 plus 00 , Table 10).

Coarse woody debris carbon in coniferous and deciduous tree forests

The estimated amount of CWD carbon for all tree species, grouped according to coniferous or deciduous tree dominated forests and calculated with increasing accuracy (Methods 1-4), is shown in Table 11. The estimated amount of CWD carbon for all species has decreased by $31 \%$ due to applying improved conversion factors for CWD (Methods 4-1). In comparison, an increased growing stock of only spruce and beech trees by $20 \%$ would increase the estimated amount of CWD carbon for the coniferous and deciduous tree forest area by $7.2 \%$ (Scenario 1 plus 11 compared to Method 4, Table 11).

The amount of CWD carbon in coniferous dominated forests is $2.6 \mathrm{t} \mathrm{C} \mathrm{ha}^{-1}$ compared to $1.9 \mathrm{t} \mathrm{C} \mathrm{ha}^{-1}$ in deciduous tree dominated forests (Table 11). This seemingly does not reflect the difference in coniferous and deciduous tree CWD volume per hectare, which differs by a factor of 4 (Table 3). The discrepancy is due to the fact that CWD carbon values in mixed forests do not reflect the source of CWD. When the actual amount of conifer CWD carbon is compared to deciduous tree CWD carbon, then they actually differ by a factor $4(2,221,000$ t $\mathrm{C}$ compared to $537,000 \mathrm{t} \mathrm{C}$ ).

Carbon estimates for all three dead wood fractions, such as CWD, LIS and DRoots, are given in Table 12. Estimates are calculated according to Methods 1 and 4. When estimates for only the CWD fraction are improved, then the total dead wood carbon estimate is reduced by $15 \%$. When all three dead wood pools are estimated according to Method 4, then the total amount of dead wood carbon would be reduced by an additional $16 \%$ compared to the original estimate using default values (Method 1). This amounts to a reduction of altogether $31 \%$, provided that the assumptions taken to estimate DRoot and LIS carbon in Method 4 can be verified.

\section{Discussion}

The estimated amount of CWD carbon is considerably reduced after improving the two conversion factors to translate CWD volume into carbon.

Including species-specific $\mathrm{C}$ concentrations, instead of using default values, reduced the estimated amount of spruce CWD carbon by $1.4 \%$ and that of beech by $4.7 \%$. 
Table 10 Estimated amount of CWD carbon, calculated according to scenario 1-5 for spruce and 11-55 for beech trees

\begin{tabular}{|c|c|c|c|c|c|c|}
\hline Scenario & $\begin{array}{l}\text { Growing stock. } \\
\left(1,000 \mathrm{~m}^{3}\right)\end{array}$ & $\begin{array}{l}\text { CWD/Grow. } \\
\text { stock }(\%)\end{array}$ & $\begin{array}{l}\text { CWD volume } \\
\left(1,000 \mathrm{~m}^{3}\right)\end{array}$ & Assumption & $\begin{array}{l}\text { CWD carbon } \\
(1,000 \text { t } \mathrm{C})\end{array}$ & $\begin{array}{l}\text { SEM } \\
(1,000 t)\end{array}$ \\
\hline \multicolumn{7}{|l|}{ Spruce } \\
\hline 1 & 214,558 & \multirow{7}{*}{5.42} & 11,353 & $+20 \%$ grow. stock spruce & 1,634 & 117 \\
\hline 2 & 196,678 & & 10,407 & $+10 \%$ grow. stock spruce & 1,539 & 114 \\
\hline 0 & 178,799 & & 9,691 & Measured NFI $3^{\mathrm{a}}$ & 1,446 & 111 \\
\hline 3 & 160,919 & & 8,528 & $-10 \%$ grow. stock spruce & 1,352 & 111 \\
\hline 4 & 143,039 & & 7,581 & $-20 \%$ grow. stock spruce & 1,259 & 110 \\
\hline \multirow[t]{2}{*}{5} & \multirow[t]{2}{*}{178,799} & & 9,691 & CWD & & \\
\hline & & & 604 & + wood for energy ${ }^{\mathrm{b}}$ & 1,552 & 116 \\
\hline \multicolumn{7}{|l|}{ Beech } \\
\hline 11 & 88,015 & \multirow{7}{*}{1.44} & 1,267 & $+20 \%$ grow. stock beech & 164 & 19 \\
\hline 22 & 80,680 & & 1,161 & $+10 \%$ grow. stock beech & 160 & 19 \\
\hline 00 & 73,346 & & 1,058 & Measured NFI $3^{\mathrm{a}}$ & 155 & 20 \\
\hline 33 & 66,011 & & 952 & $-10 \%$ grow. stock beech & 151 & 21 \\
\hline 44 & 58,677 & & 846 & $-20 \%$ grow. stock beech & 146 & 23 \\
\hline \multirow[t]{2}{*}{55} & 73,346 & & 1,058 & CWD & & \\
\hline & & & 1,336 & + wood for energy $^{c}$ & 521 & 42 \\
\hline
\end{tabular}

${ }^{\text {a }}$ Species-specific C concentration, CWD density predicted using climate models, Method 4 Table 9

b Wood for energy' carbon calculated as alive wood, density $=0.36 \mathrm{~g} \mathrm{~cm}^{-3}, \mathrm{C}$ concentration $=48.3 \%$

${ }^{c}$ Wood for energy' carbon calculated as alive wood, density $=0.58 \mathrm{~g} \mathrm{~cm}^{-3}, \mathrm{C}$ concentration $=46.8 \%$

Table 11 Estimated amount of CWD carbon for coniferous or deciduous tree dominated forests and the whole accessible forest area of Switzerland, using Methods 1-4 and scenario 1 and 11

a An increased volume of CWD was assumed for spruce and beech, but not for other coniferous or deciduous tree species

\begin{tabular}{llllll}
\hline Method & $\begin{array}{l}\text { Conifer } \\
\text { dominated forest }\end{array}$ & SEM & $\begin{array}{l}\text { Deciduous } \\
\text { tree dominated forest }\end{array}$ & SEM & Total \\
\hline CWD carbon (1,000 t C) & & & & & \\
$\quad$ Method 1 & 2,613 & 482 & 1,373 & 204 & 3,987 \\
Method 2 & 2,570 & 468 & 1,323 & 194 & 3,893 \\
Method 3 & 1,993 & 233 & 835 & 110 & 2,828 \\
Method 4 & 1,941 & $(333)$ & 817 & $(110)$ & 2,758 \\
Scenario 1, 11 & 2,181 & 254 & 864 & 111 & 3,045 \\
Method 4 & & & & \\
Area (ha) & 749,841 & & 422,365 & & $1,172,206$ \\
CWD carbon ( $\left.\mathrm{t} \mathrm{ha}^{-1}\right)$ & 2.6 & 1.9 & & 2.4 \\
\hline
\end{tabular}

Table 12 Carbon in the CWD, LIS and DRoot fractions of the dead wood carbon pool, as estimated using Method 1 or 4

\begin{tabular}{lllll}
\hline $\begin{array}{l}\text { Method } \\
(1,000 \mathrm{t} \text { C })\end{array}$ & CWD carbon & LIS carbon & DRoot carbon & CWD, LIS, DRoot carbon \\
\hline 1 & 3,987 & 2,030 & 2,241 & 8,258 \\
4 & - & - & - & 7,029 \\
1 & - & 2,030 & 2,241 & - \\
4 & 2,758 & - & - & 5,712 \\
1 & - & - & $1,550^{\mathrm{a}}$ &
\end{tabular}

a Calculated under following assumptions: (1) volume ratios between decay class 1-4 were similar as for CWD, (2) density in decay class 1-4 was reduced in a similar way as for CWD 
Our implemented $\mathrm{C}_{105}$ concentration for $F$. sylvatica $C W D$ of $47.6 \%$ is slightly lower than values published for $F$. sylvatica growing in a moderately oceanic climate in North Rhine-Westphalia in Germany of 48.9-50.7\% (Joosten et al. 2004). The implemented $\mathrm{C}_{105}$ concentration for Picea abies CWD of $49.3 \%$ is in accordance with values determined in alpine regions $(49.7 \% \mathrm{C})$ or in Scandinavia (50.3\% C) (Bütler et al. 2007; Sandström et al. 2007). The estimate of coniferous and deciduous CWD carbon was reduced by $2.4 \%$ due to refining the value for $\mathrm{C}_{105}$ concentration (Table 11).

Historically wood was dried at $105^{\circ} \mathrm{C}$ to determine water content. However, recent studies found that $\mathrm{C}$ concentration is lower when wood is dried at $105^{\circ} \mathrm{C}$ compared to $65^{\circ} \mathrm{C}$ due to a loss of volatile carbon at higher temperatures. However, when samples are dried at $65^{\circ} \mathrm{C}$, then the calculated $\mathrm{C}$ concentration, a ratio of $\mathrm{C}$-mass to samplemass, is slightly lower compared to samples dried at $105^{\circ} \mathrm{C}$ (Bert and Danjon 2006), due to some water remaining in the sample dried at $65^{\circ} \mathrm{C}$. The remaining water content (Bert and Danjon 2006; Lamlon and Savidge 2003) needs to be determined and corrected for.

We have done this in our studies. However, omitting this correction step would have caused a difference of $4 \%$ instead of $2.4 \%$ in the estimated amount of CWD carbon due to applying species-specific $\mathrm{C}_{65}$ concentrations (Table 11). This shows the diligence required in stating methods and also a level of uncertainty, when comparing estimated carbon data from different sources, unless their method is provided in detail. To put this in perspective, uncertainty in measuring CWD volume in the field is about $6 \%$ (twice relative standard error, Table 3) (IPCC 2003). Although the error due to applying a standard $\mathrm{C}$ concentration appears low compared to the uncertainty of the CWD volume measurement, it is an additional source of error that can be avoided with feasible means.

Implementing decay class-specific CWD density values, the second conversion factor changes the estimated amount of CWD carbon most significantly by $17.8 \%$ for spruce and $41.6 \%$ for beech. The estimated amount of CWD carbon for the whole forest area in Switzerland is reduced by $27 \%$ (Table 11), stressing the importance of this conversion factor. This is due to the fact that CWD density decreases significantly with an increase in decay class, which has been observed previously for spruce and beech (Bütler et al. 2007; Harmon et al. 1987; 2000; Kahl 2008; Krankina and Harmon 1995; Means et al. 1985; Müller-Using and Bartsch 2009; Sandström et al. 2007; Yatskov et al. 2003). A comparison of CWD density values is difficult, since most often CWD classification systems differ between studies. The range of CWD density determined in Scandinavian open forest of $0.41-0.19 \mathrm{~g} \mathrm{~cm}^{-3}$ (Naesset 1999a) was close to our determined range of $0.39-0.24 \mathrm{~g} \mathrm{~cm}^{-3}$, whereas the values determined by Bütler et al. (2007) were slightly higher $\left(0.43-0.31 \mathrm{~g} \mathrm{~cm}^{-3}\right)$. For beech, our CWD density range of $0.52-0.22 \mathrm{~g} \mathrm{~cm}^{-3}$ was close to the range determined by Kahl (2008) of $0.50-0.25 \mathrm{~g} \mathrm{~cm}^{-3}$. Although ranges are not directly comparable, it is clear that CWD density is reduced significantly with an increased state of decay. Additionally, the average density of alive trees, the previously used conversion factor, is even higher than our maximum CWD density values. The density of $P$. abies trees was found to be between 0.37 and $0.57 \mathrm{~g} \mathrm{~cm}^{-3}$ and that of $F$. sylvatica trees between 0.58 and $0.85 \mathrm{~g} \mathrm{~cm}^{-3}$ (Gryc and Horacek 2007; Skomarkova et al. 2006).

The conversion factor CWD density is further refined by using climate-based models to predict site-specific CWD density. This further improvement reduces the estimated amount of CWD carbon for spruce by $3.9 \%$ and for beech by $1.3 \%$. The explanatory, climatic variables in models differed for the four decay stages possibly in line with climatic optima of the dominant decomposing organisms in each phase. Rainfall is a dominant factor that determined spruce CWD density, predominantly in decay class 1 and 3 . Temperature and potential evapotranspiration are important in decay class 1,2 and 4. The importance of rainfall in early decay stages may be due to the fact that the first phase of decomposition is that wood assumes a moisture status suitable for decomposer organisms (Grier 1978; Harmon et al. 2000; Laiho and Prescott 1999; Meentemeyer 1978). However, the amount of variability explained by our climate models decreased with proceeding decay, at least for spruce CWD. Berg and Meentemeyer (2002) have shown that the direct influence of climate on decomposition can vanish during the late stages of decomposition. This might explain the relatively loose correlation between density and climate attributes at later decay stages.

The climate models are of limited use to predict beech CWD density. Parameters for litter quality, such as initial wood density or lignin to $\mathrm{N}$ ratio, have been reported to influence decomposition (Berg and Meentemeyer 2002; Mackensen et al. 2003). Including initial wood density actually improved our models, particularly for beech CWD (data not shown). However, widespread data coverage for tree density is not available, and modeling this parameter would create an additional source of variation. Therefore, we did not include those parameters in our models.

The $\mathrm{N}$ or lignin concentrations also have been shown to influence decomposition of litter or woody debris and the decomposition rate of angiosperm wood (Berg and $\mathrm{Me}$ entemeyer 2002; DeSanto et al. 2009; Taylor et al. 1989; Weedon et al. 2009). Although we appreciate this fact, we did not include $\mathrm{N}$ concentration as a variable in the regression analysis, due to the lack of widespread data coverage.

The moderate explanatory value of local climate to predict CWD density may also be partly due to the fact that 
our data were already classified into four decay classes. Those decay classes are already the result of past decay processes. However, each of the broad decay classes, determined with coarse field test, includes CWD of a fair time span in the general decay process. Decay processes and climatic influences on those are deemed to take place within each decay class but on a much smaller time scale as in the overall decomposition process. This small scale in time may be the reason that the variation of CWD density within a decay class is too limited to be able to show tight correlations between density and climate influences.

Using improved conversion factors, we calculated the amount of CWD carbon that originated from spruce and beech trees for each region in Switzerland. It is obvious that by far the biggest amount of CWD carbon is stored as spruce CWD in the Pre-Alps and Alps. The difference in CWD carbon is foremost based on a four times difference in CWD volume per hectare between spruce and beech (Table 3). A difference in CWD volume per hectare in the same order of magnitude has been reported previously for managed stands of spruce and deciduous trees (Bretz-Guby and Dobbertin 1996; Gough et al. 2007; Vogt 1991). Differences in CWD carbon between coniferous and deciduous tree dominated forests appear lower in comparison (Table 11). Comparing coniferous and deciduous tree dominated forests disguises the fact that most CWD volume and CWD carbon actually originates from coniferous trees, even in mixed forests of Switzerland (Table 3, Fig. 4). As a consequence, changes in the conversion factors for coniferous CWD affect the estimated CWD carbon pool most profoundly due to the predominant amount of coniferous CWD, although the relative changes in estimated CWD carbon for spruce and beech after improving conversion factors had suggested the reverse (Table 9).

The significant difference in CWD volume between spruce and beech could be based on a difference in tree mortality, CWD decay rate and forest management. Indeed, annual mortality rates of spruce trees were found to be twice as high compared to beech trees (Dobbertin et al. 2002), and the following storm events mortality was found to differ by a factor of 2.5-10 (Dobbertin et al. 2002; NWFVA 2008). Furthermore, the decay rate constant for spruce wood is almost three times lower than that of beech wood under European conditions (Müller-Using and Bartsch 2009; Naesset 1999b; Rock et al. 2008) (Fig. 1). For example, a $77 \%$ difference in decay rate constant, as found between gymnosperm and angiosperm wood, translates into a $44 \%$ reduction in the size of the woody debris pool (Weedon et al. 2009). Also forest management differs between species, partly because spruce is more prevalent than beech on mountainous, low accessible area. A survey has shown that $45 \%$ of Pre-Alps and Alps forests are not deemed to need urgent management in the next 20 years compared to $13 \%$ of the Plateau and Jura forests (Speich et al. 2010).

The improved conversion factors that translate dead wood volume into carbon are currently applied to the CWD but not to the LIS and DRoot fraction of the dead wood pool. However, the LIS and DRoot fractions are considerable sources of dead wood volume as well, with the two of them being about equal in volume compared to the CWD fraction. Currently carbon for the LIS and DRoot fractions is still estimated according to Method 1 (using default values). Including improved conversion factors reduced the estimated amount of CWD carbon by $30.8 \%$ and carbon from the three dead wood fractions by $15 \%$ (Table 11, 12). Reductions in estimated carbon of the same magnitude as for the CWD carbon can be expected for the LIS and DRoot fractions, once improved conversion factors are established. This would reduce the estimated amount of dead wood carbon additionally by another $16 \%$, which means a reduction by altogether $31 \%$ compared to estimated dead wood carbon using default values (Table 12) can be expected. Hence, uncertainties about conversion factors for the LIS and DRoot fractions should be addressed soon.

The amount of dead wood carbon is calculated on the basis of $\mathrm{C}$ concentration, wood density and volume, which in turn can be influenced by a range of factors. Those factors can be broadly grouped into two categories a) factors given by tree physiology and environmental conditions and b) factors that can be influenced by human interventions.

The CWD C concentration and CWD density are mainly influenced by factors from the first category and thus only the measurement of the resulting values can be improved. The CWD volume is mainly influenced by factors of the second category, such as forest management and selection of tree species. The CWD volume in managed forests is usually considerably lower compared to unmanaged forests (Bretz-Guby and Dobbertin 1996; Christensen et al. 2005). In unmanaged forests CWD volumes of $90-120 \mathrm{~m}^{3} \mathrm{ha}^{-1}$ have been reported for spruce forests and $130 \mathrm{~m}^{3} \mathrm{ha}^{-1}$ for beech forests (Christensen et al. 2005; Siitonen 2001) compared to our measured volumes of 20.2 and $4.7 \mathrm{~m}^{3}$ $\mathrm{ha}^{-1}$ in managed spruce and beech areas, respectively. Concluding from those numbers, there is still leeway to increase CWD volume and thus CWD carbon in managed forests of Switzerland. Switzerland has decided to include forest management in their accounting of GHG emissions and removals. The reduced extraction of CWD, particularly in spruce forests, could be a feasible tool to increase the amount of carbon stored in Swiss forests and thus create a management-based carbon sink.

Acknowledgments The authors would like to thank the Federal office for the Environment (FOEN) for the financial support of this study and the financial support of one of the authors. We want to 
thank Kalin Müller (Waldresourcen und Waldmanagement, WSL) for preparing the map of sampling sites. Furthermore, we want to thank the staff at the central laboratory of the WSL for conducting chemical analysis of samples and Magdalena Nötzli for the estimation of water content in the samples.

\section{References}

Assmann E (1961) Waldertragskunde. BLV Verlagsgesellschaft, München

Berg B, Meentemeyer V (2002) Litter quality in a north European transect versus carbon storage potential. Plant Soil 242:83-92

Bert D, Danjon F (2006) Carbon concentration variations in the roots, stem and crown of mature Pinus pinaster (Ait.). For Ecol Manag 222:279-295

Böhl J, Brändli U-B (2007) Deadwood volume assessment in the third Swiss National Forest Inventory: methods and first results. Eur J Forest Res 126:449-457

Brändli U-B, Abegg M, Duc P, Ginzler C (2010) Biologische Vielfalt. In: Brändli UB (ed) Schweizerisches Landesforstinventar. Ergebnisse der dritten Erhebung 2004-2006. Eidgenössische Forschungsanstalt für Wald, Schnee und Landschaft WSL; Bundesamt für Umwelt BAFU, Birmensdorf, pp 31-113

Bretz-Guby NA, Dobbertin M (1996) Quantitative estimates of coarse woody debris and standing dead trees in selected Swiss forests. Global Ecol Biogeogr Lett 5:327-341

Bütler R, Patty L, LeBayon R, Guenat C, Schlaepfer R (2007) Log decay of Picea abies in the Swiss Jura Mountains of central Europe. For Ecol Manag 242:791-799

Christensen M, Hahn K, Mountford EP, Odor P, Standovar T, Rozenbergar D, Diaci J, Wijdeven S, Meyer P, Winter S, Vrska $\mathrm{T}$ (2005) Dead wood in European beech (Fagus sylvatica) forest reserves. For Ecol Manag 210:267-282

Cioldi F, Baltensweiler A, Brändli UB, Duc P, Ginzler C, Bonardi AH, Thürig E, Ulmer U (2010) Waldressourcen. In: Brändli UB (ed) Schweizerisches Landesforstinventar. Ergebnisse der dritten Erhebung 2004-2006. Eidgenössische Forschungsanstalt für Wald, Schnee und Landschaft WSL; Bundesamt für Umwelt BAFU, Birmensdorf, pp 31-113

DeSanto AV, DeMarco A, Fierro A, Berg B, Rutigliano FA (2009) Factors regulating litter mass loss and lignin degradation in late decomposition stages. Plant Soil 318:217-228

Dobbertin M, Seifert H, Schwyzer A (2002) Standort und Bestandesaufbau waren mitentscheidend für das Ausmass der Sturmschäden. Wald und Holz 83:39-42

FOEN (2009) Switzerlands greenhouse gas inventory 1990-2007, National Inventory Report 2009, Submission of the 15. April 2009 under the United Nations Framework Convention on Climate Change and under the Kyoto Protocol. www.climatereporting.ch; Federal Office for the Environment (FOEN), Bern

Gough CM, Vogel CS, Kazanski C, Nagel L, Flower CE, Curtis PS (2007) Coarse woody debris and the carbon balance of a north temperate forest. For Ecol Manag 244:60-67

Grier CC (1978) A Tsuga heterophylla - Picea sitchensis ecosystem of coastal Oregon: decomposition and nutrient balances of fallen logs. Can J For Res 8:198-206

Gryc V, Horacek P (2007) Variability in density of spruce (Picea abies [L.] Karst.) wood with the presence of reaction wood. J For Sci 53:129-137

Harmon ME, Franklin JF, Swanson FJ, Sollins P, Gregory SV, Lattin JD, Anderson NH, Cline SP, Aumen NG, Sedell JR, Lienkaemper GW, Cromack K, Cummnins JR, Cummnins KW (1986) Ecology of coarse woody debris in temperate ecosystems. Adv Ecol Res 15:133-302
Harmon ME, Cromack K, Smith BG (1987) Coarse woody debris in mixed conifer forests, Sequoia National Park, California. Can J For Res 17:1265-1272

Harmon ME, Krankina ON, Sexton J (2000) Decomposition vectors: a new approach to estimating woody detritus decomposition dynamics. Can J For Res 30:76-84

Heim A, Frey B (2004) Early stage litter decomposition rates for Swiss forests. Biogeochemistry 70:299-313

Innes JL (1995) Theoretical and practical criteria for the selection of ecosystem monitoring plots in Swiss forests. Environ Monit Assess 36:271-294

IPCC (1997) Revised 1996 IPCC guidelines for national greenhouse gas inventories

IPCC (2003) Good practice guidance for land use, land use change and forestry Institute for Global Environmental Studies (IGES), Hayama

Joosten R, Schumacher J, Wirth C, Schulte A (2004) Evaluating tree carbon predictions for beech (Fagus sylvatica L.) in western Germany. For Ecol Manag 189:87-96

Kahl T (2008) Kohlenstofftransport aus dem Totholz in den Boden. Dissertation University of Freiburg. http://www.freidok.unifreiburg.de/volltexte/5522/

Kaufmann E (2001) Estimation of standing timber, growth and cut. In: Brassel P, Lieschke H (eds) Swiss national forest inventory: methods and models of the second assessment. WSL Swiss Federal Research Institute, Birmensdorf, pp 162-196

Kaufmann E, Brassel P (1999) Holzvorrat, Zuwachs und Nutzung. In: Brassel P, Brändli U-B (eds) Schweizerisches Landesforstinventar. Ergebnisse der Zweitaufnahme 1993-1995. Eidgenössische Forschungsanstalt für Wald, Schnee und Landschaft WSL; Bundesamt für Umwelt, Wald und Landschaft BUWAL, Birmensdorf, pp 31-113

Keller M (2005) Schweizerisches Landesforstinventar-Anleitungen für die Feldaufnahmen der Erhebungen 2004-2007. Eidg. Forschungsanstalt WSL, Birmensdorf

Krankina ON, Harmon ME (1995) Dynamics of the dead wood carbon pool in Northwestern Russian boreal forests Water. Air Soil Pollut 82:227-238

Kurz-Besson C, Couteaux MM, Berg B, Remacle J, Robeiro C, Romanya J, Thiery JM (2006) A climate response function explaining most of the variation of the forest floor needle mass and the needle decomposition in pine forest across Europe. Plant Soil 285:97-114

Laiho R, Prescott CE (1999) The contribution of coarse woody debris to carbon, nitrogen and phosphorus cycles in three Rocky Mountain coniferous forests. Can J For Res 29:1592-1603

Laiho R, Prescott CE (2004) Decay and nutrient dynamics of coarse woody debris in northern coniferous forests: a synthesis. Can J For Res 34:763-777

Lamlon SH, Savidge RA (2003) A reassessment of carbon content in wood: variation within and between 41 North American species. Biomass Bioenerg 25:381-388

Liski J, Nissinen A, Erhard M, Taskinen O (2003) Climatic effects on litter decomposition from arctic tundra to tropical rainforest. Glob Change Biol 9:575-584

Mackensen J, Bauhus J, Webber E (2003) Decomposition rates of coarse woody debris - a review with particular emphasis on Australian tree species. Aust J Bot 51:27-37

Means JE, Cromack K, MacMillan PC (1985) Comparison of decomposition models using wood density of Douglas fir logs. Can J For Res 15:1092-1098

Meentemeyer V (1978) Macroclimate and lignin control of litter decomposition rates. Ecology 59:465-472

Müller-Using S, Bartsch N (2009) Decay dynamic of coarse and fine woody debris of a beech (Fagus sylvatica $\mathrm{L}$.) forest in Central Germany. Eur J Forest Res 128:287-296 
Naesset E (1999a) Relationship between relative wood density of Picea abies logs and simple classification systems of decayed coarse woody debris. Scand J For Res 14:454-461

Naesset E (1999b) Decomposition rate constants of Picea abies logs in southeastern Norway. Can J For Res 29:372-381

NW-FVA (2008) Nordwestdeutsche Forstliche Versuchsanstalt: Ergebnisse angewandter Forschung zur Buche, Beiträge aus der Nordwestdeutschen Forstlichen Versuchsanstalt. Band 3. www. nw-fva.de/index.php?id=339; Universitätsdrucke Göttingen

Rock J, Badeck FW, Harmon ME (2008) Estimating decomposition rate constants for European tree species from literature sources. Eur J Forest Res 127:301-313

Sandström F, Petersson H, Kruys N, Stahl G (2007) Biomass conversion factors (density and carbon concentration) by decay classes for dead wood of Pinus sylvestris, Picea abies and Betula spp. in boreal forests of Sweden. For Ecol Manag 243:19-27

Siitonen J (2001) Forest management, coarse woody debris and saproxylic organisms. Fennoscandian boreal forests as an example. Ecol Bull 49:11-41

Skomarkova MV, Vaganov EA, Mund M, Knohl A, Linke P, Boerner A, Schulze E-D (2006) Inter-annual and seasonal variability of radial growth, wood density and carbon isotope ratios in tree rings of beech (Fagus sylvatica) growing in Germany and Italy. Trees Struct Funct 20:571-586

Speich S, Abegg M, Brändli UB, Cioldi F, Duc P, Keller M, Meile R, Rösler E, Schwyzer A, Ulmer U, Zandt H (2010). National forest inventory Drittes Schweizerisches Landesforstinventar - Ergebnistabellen im Internet, in:http://www.lfi.ch/resultate/ (ed) Eidg. Forschungsanstalt WSL, Birmensdorf

Swiss_Forestry_Statistics (2010) Erhebungen, Quellen- Schweizerische Forststatistik. http://www.bfs.admin.ch/bfs/portal/de/index/ infothek/erhebungen__quellen/blank/blank/forst_stat/01.html; Bundesamt für Statistik, Schweiz

Taylor BR, Parkinson D, Parsonns WFJ (1989) Nitrogen and lignin content as predictors of litter decay rates: a microcosm test. Ecology 70:97-104
Thornton PE, Running SW, White MA (1997) Generating surfaces of daily meteorological variables over large regions of complex terrain. J Hydrol 190:214-251

Tomppo E, Gschwantner T, Lawrence M, McRoberts RE (2010) National forest inventories. Pathways for common reporting. Springer, Heidelberg

Turc L (1963) Evaluation des besoins en eau d'irrigation, evapotranspitaion potentielle, formulation simplifie et mise a jour. Ann Agron 12:13-49

Vogt K (1991) Carbon budget of temperate forest ecosystems. Tree Physiol 9:69-86

Weedon JT, Cornwell WK, Cornelissen JHC, Zanne AE, Wirth C, Coomes DA (2009) Global meta-analysis of wood decomposition rates: a role for trait variation among tree species. Ecol Lett $12: 45-56$

Wirth C, Schumacher J, Schulze E-D (2004) Generic biomass functions for Norway spruce in Central Europe-a meta-analysis approach toward prediction and uncertainty estimation. Tree Physiol 24:121-139

Woodall CW, Rondeux J, Verkerk PJ, Stahl G (2009) Estimating dead wood during national Forest inventories: a review of inventory methodologies and suggestions for harmonization. Environ Manage 44:624-631

WSL (2010) Langfristige Waldökosystemforschung (LWF). http:// www.wsl.ch/dienstleistungen/inventare/lwf/index_DE; Eidg. Forschungsanstalt für Wald, Schnee und Landschaft (WSL)

Wutzler T, Wirth C, Schumacher J (2008) Generic biomass functions for common beech (Fagus sylvatica) in Central Europe: predictions and components of uncertainty. Can J For Res 38:1661-1675

Yatskov M, Harmon ME, Krankina O (2003) A chronosequence of wood decomposition in the boreal forests of Russia. Can J For Res 33:1211-1226

Yin X (1999) The decay of forest woody debris: numerical modeling and implications based on some 300 data cases from North America. Oecologia 121:81-98 